\title{
Arte y publicidad: del arte pop a la crítica insti- tucional
}

\author{
Jaime VINDEL GAMONAL \\ Universidad de León
}

\begin{abstract}
RESUMEN. El artículo plantea un recorrido que analiza cómo la aparición de nuevas modalidades artísticas desde los años 60, que proclamaban la ruptura con el formalismo y la autonomía del arte tardomoderno, posibilitaron la apertura de una relación dialéctica alternativa con el imaginario de la industria cultural y, más concretamente, con el de la publicidad. El estudio parte de la descripción de algunas producciones que se suelen adscribir al arte pop y el conceptualismo, enfatizando su implicación crítica tanto en contextos no institucionales como en los denominados «periféricos». En un segundo bloque, se establece a partir de las prácticas precedentes una genealogía de corrientes posteriores, que conjugan la intervención urbana y la crítica institucional con el abordaje de cuestiones relativas a la identidad o el género.
\end{abstract}

Palabras clave: Formalismo, arte pop, arte conceptual, política, publicidad, intervenciones urbanas, cuestiones de género, crítica institucional.

ABSTRACT. The article analyzes how the appearance of new forms of art since the 60 's, claiming the break with the formalism and the autonomy of last-modern art, enabled the opening of an alternative dialectical relationship with the imaginary of the culture industry, and more specifically with the advertising. The study part of the description of some productions which are usually attached to pop and conceptual art, emphasizing his critical involvement in noninstitutional contexts as in called «peripheral». In the second part, the text focus on subsequent practices that combine urban intervention and institutional criticism with the interest in identity or feminist issues.

Key words: Formalism, pop art, conceptual art, politics, advertising, urban interventions, feminism, institucional criticism.

\section{LOS AÑOS 60: LA EMERGENCIA DEL} $P O P$ Y EL CONCEPTUALISMO

Para situar históricamente la reflexión que deseo realizar en torno a las relaciones entre arte crítico y publicidad ${ }^{1}$ es

-

${ }^{1}$ El término «publicidad» poseía, en el castellano de finales del siglo XIX, un sentido más amplio que el actual. En efecto, hasta entonces «publicidad» era sinónimo de «vida social pública», connotación que prevalece en el alemán contemporáneo en el concepto de offenlichkeit. Traducido a menudo como «esfera pública», el concepto ha encontrado su mejor elaboración en los textos de Jürgen Habermas (véase al respecto la nota de Antonio Doménech a la edición española, en: J. HABERMAS, Historia y crítica de la opinión pública. La transformación estructural de la vida pública, Barcelona, 2000, p. 40; además de la obra de Habermas, resulta ineludible la consulta del artículo de A. KLUGE y O. NEGT, «Esfera pública y experiencia. Hacia un análisis de las esferas públicas burguesa y proleta- 
necesario apuntar la emergencia de nuevos planteamientos artísticos desde los años 60, que posibilitaron la reconsideración del binomio arte-política durante las décadas inmediatamente posteriores.

Esas propuestas postergaron el autoritarismo de la crítica formalista americana, representada por críticos como Clement Greenberg o Michael Fried, quienes instituyeron su relato del modernismo a partir del expresionismo abstracto. Dicho relato, que concluía con la llamada «abstracción postpictórica», abogaba por la autonomía del arte $\mathrm{y}$, más concretamente, por la pureza de la pintura como medio específico. Una pureza en la que la idea de «planitud» (flatness) aparecía como objetivo esencial, razón por la cual la superficie del lienzo debía desprenderse de cualquier huella del trabajo del artista, del pigmento $\mathrm{y}$, en última instancia, del soporte pictórico, conformando una imagen atemporal y ahistórica cuya carga neoplatónica ya se encargó de subrayar convenientemente Victor Burgin².

ria», Modos de hacer. Arte crítico, esfera pública y acción directa, Salamanca, 2001, pp. 227-271). Según señalara Benjamin Buchloh, la reducción de la publicidad al anuncio, tal y como la concebimos hoy en día, comportaría el manejo de un uso del término opuesto al habermarsiano, en el que radicaría «la privatización comercial de la experiencia pública» característica del modelo social burgués (véase B. BUCHLOH, «Estructura, signo y referencia en la obra de David Lamelas», David Lamelas: extranjero, foreigner, étranger, ausländer, México D.F. / Buenos Aires, 2006, p. 25.). Aquí me restringiré al estudio de la relación entre el arte contemporáneo y la publicidad comercial; para otro momento habrá de quedar el análisis de las propuestas del arte último que tratan de reconfigurar la esfera pública heredada de la modernidad.

2 Véase V. BURGIN, «Ver el sentido», Efecto real. Debates posmodernos sobre fotografía, Barcelona, 2004, p. 183. En su crítica de la teoría greenbergiana, Burgin se remite, citando a E.H. Gombrich, al Fedón platónico, para afirmar a continuación: «La idea de que existen dos formas diferenciadas de comunicación, las palabras y las imágenes, y de que éstas últimas son la forma más directa, pasó a través del neoplatonismo a la tradición cristiana, que defendió la existencia de un
En lo relativo a algunas de las corrientes contestatarias que veremos a continuación, la renovación del arte se hizo tanto más acuciante cuando, en un escenario violentado por el feminismo, las reivindicaciones anti-racistas y la guerra de Vietnam, comenzó a ser vox populi que algunas de las muestras de pintura norteamericana en el MOMA habían sido subvencionadas por la CIA, quien predicaba el apoliticismo del arte abstracto americano como estrategia de resistencia a la infiltración en ese contexto del realismo socialista del bloque del Este, una sospecha que se vería confirmada por el artículo que Eva Cockcroft publicó bajo el título de «Expresionismo abstracto, armas y Guerra Fría» en junio de 1971 en la revista Artforum ${ }^{3}$.

No es casual que, por ese motivo, el colectivo Art Workers Coalition, con Ronald Haeberle y Peter Brandt a la cabeza, eligiera el Museo de Arte Moderno para llevar una de las copias de su poster $Q$. And babies? A. And babies, que a modo de protesta por la política internacional de su país, cuyos intereses se confabulaban con los del referido museo, fue colocado junto al Guernica de Picasso. Según destaca Tony Godfrey, «los miembros del consejo de administración del museo eran los mismos que poseían las mayores compañías americanas que proveían de maquinaria de guerra» al ejército americano en Vietnam ${ }^{4}$. Este asunto, el de la guerra en Lejano Oriente, vertebrará a nivel internacional la politización

lenguaje divino de las cosas, más rico que el lenguaje de las palabras; quien aprehende las verdades difíciles, aunque divinas, que atesoran las cosas lo hace en un abrir y cerrar de ojos, sin necesidad de palabras ni argumentaciones». Para una síntesis revisionista del pensamiento de Greenberg, véase T. DE DUVE, Clement Greenberg entre líneas, Santa Cruz de Tenerife, 2005.

${ }^{3}$ Véase T. CLARK, Arte y propaganda en el siglo XX. La imagen política en la era de la cultura de masas, Madrid, 2001, p. 130.

${ }^{4}$ Véase T. GODFREY, Conceptual Art, Londres, 1998, p. 242. 
del arte durante finales de los $60 \mathrm{y}$ principios de los 70 .

Dejando a un lado esta contingencia histórico-política para centrarnos en un punto de vista iconográfico, la publicidad ha sabido asumir el universo antropocéntrico y el ímpetu mimético en la representación que desde el Renacimiento había caracterizado la tradición artística occidental. Según afirmara John Berger, «[la publicidad] convierte toda la historia en una sucesión de mitos, pero para hacerlo con eficacia necesita un lenguaje visual de dimensiones históricas», que tomaría de la tradición pictórico-escultórica ${ }^{5}$. Frente a ello, ciertas vanguardias históricas y el arte de posguerra trataron de consolidar su autonomía - sobre todo por la vía de la abstracción - como modo de ejercer una resistencia a la realidad social en términos de verdad negativa, dejando de este modo el terreno libre para que fuera la publicidad quien configurara el imaginario colectivo. Una negatividad que, por otra parte, se vio potenciada por la reclusión del arte en el ámbito institucional entendido como lugar de preservación cultural. Esta aporía tratará de ser salvada tanto por el arte pop como por ciertos desarrollos del arte conceptual, hitos fundamentales del cisma con el formalismo tardomoderno cuya herencia se extiende hasta nuestros días. En el caso del pop, la línea divisoria se trazará a partir de la incorporación de la iconografía de la sociedad de consumo, postergando así la división entre alta y baja cultura. En el del conceptual, cuestionando tanto la prioridad otorgada por Greenberg a la capacidad comunicativa de la pura imagen atemporal - motivo por el cual los artistas decidieron introducir la palabra en sus obras - como la legitimidad de las instancias y espacios del arte, lo que les condujo a realizar inter-

\footnotetext{
${ }^{5}$ Véase J. Berger, Modos de ver, Barcelona, 2000, p.
}

venciones en contextos ajenos a las instituciones.

\section{EL POP ART Y SU INVERSIÓN CRÍTICA}

Las relaciones entre arte y publicidad han variado desde finales del siglo XIX hasta el presente. En un principio, la publicidad se nutría de los «modelos de representación del arte» ${ }^{6}$. La posterior aparición de diversas técnicas de impresión favorecerá la extensión de la imagen publicitaria por la integridad del medio urbano, de manera que el arte se verá impelido progresivamente a incorporar referencias extraartísticas como modo de cuestionar su naturaleza autónoma y ahistórica. Si bien esta problemática se presenta con prontitud en vanguardias históricas como el cubismo ${ }^{7}$, será sobre todo a partir de finales de los años 50 y principios de los 60 del siglo XX, con la emergencia del arte pop y el nuevo realismo, cuando el arte trate de aproximarse a un modelo estético que, por utilizar los términos empleados por Clement Greenberg, aspiraba a sintetizar la dialéctica entre vanguardia y kitsch. Ese intento de ampliación de los límites de la estética derivó, por el contrario, en una estetización de la vida cotidiana que venía a confirmar el diagnóstico heideggeriano de la globalización de la estética como uno de los rasgos capitales de la modernidad ${ }^{8}$.

\footnotetext{
${ }^{6}$ Véase J. C. PÉREZ GAULI, El cuerpo en venta. Relación entre arte y publicidad, Madrid, 2000, p. 11.

${ }^{7}$ Este sentido anticipatorio del cubismo ha sido señalado, entre otros, por C. POGGI, «La structure allégorique du collage de Picasso», Langage et modernité, Villeurbanne, 1991, pp. 21-45.

${ }^{8}$ Véase M. HeIDEGGER, «La época de la imagen del mundo», Caminos de bosque, Madrid, 1995, pp. 63-90. Para Félix Duque, los escritos de Guy Debord o Jean Baudrillard no hacen sino llevar al paroxismo tal diagnóstico: véase F. DUQUE, «Introducción. La verdad puesta en obra», Heidegger y el arte de verdad, Pamplona, 2005, pp. 32-33.
} 
Centraré mi análisis del arte pop en su figura más popular: Andy Warhol. En un principio, si nos ceñimos a un plano estrictamente formal, el carácter serial de las imágenes warholianas, la repetición como rasgo característico en la representación de los grandes iconos y celebridades, podría ejercer un carácter desmitificador sobre esas imágenes. En este aspecto, siguiendo los comentarios de Gilles Deleuze en su libro La lógica del sentido, el carácter repetitivo de las composiciones warholianas establecía las condiciones de lo que el filósofo francés denominaba «simulacro», en el que la imagen perdía su sentido único, aurático o cultual (según fuera tematizado por Walter Benjamin $^{9}$ ) al resultar indiscernible la copia del original ${ }^{10}$.

Pero cabe otra lectura, que tal vez sea más ambiciosa desde el punto de vista de las relaciones entre arte y publicidad, ya que podríamos ver en la multiplicación de la imagen comercial (como, por ejemplo, en la serie de las sopas Campbell) un modo de constatar formalmente el triunfo de la publicidad sobre el arte en lo relativo a la democratización de sus productos desde la implantación del régimen fordista de producción. Allí donde Walter Benjamin postulaba una nueva era del arte protagonizada por las técnicas de reproductibilidad que, como la fotografía, permitirían postergar el aura del objeto único de arte, la publicidad impuso mediante la imagen de marca, en sentido inverso, su ideología de consumo, basada en la dotación de aura a productos que, de por sí, responden a la serialidad de la producción. Ese proceso es testificado por Warhol al introducir la representación seriada de uno de esos productos en el ámbito del arte, sabedor de que

-

${ }^{9}$ Véase W. BENJAMIN, «La obra de arte en la época de su reproductibilidad técnica», Obras, Madrid, Libro I/ vol. 2, 2008, pp. 7-85.

${ }^{10}$ G. DeLEUZE, Lógica del sentido, Barcelona, 1971, p. 234. la carga aurática reside en la publicidad común a ambos - entendida en este caso como el modo de hacerse públicos- y no en el tipo de producto artístico o comercial que se realice.

Este aspecto fue sintetizado y desarrollado hasta sus últimas consecuencias en las famosas Brillo Box (Lám. 1). Expuestas por primera vez en la Galería Stable en el año 1964, las Brillo Box responden a la introducción de un diseño comercial en el contexto del arte, sin que el objeto sufra ninguna alteración por parte del artista. El diseño, realizado a su vez por otro artista, ya había pasado, según refiere Arthur Danto, «algún tipo de prueba estética»: la relativa a su comercialización ${ }^{11}$. La introducción de ese producto en el ámbito del arte le confiere una plusvalía que reside en el modo en que su indiscernibilidad con el producto comercial dispara la reflexión en torno a la conceptualización institucional de la naturaleza del arte.

En todo caso, si bien es adecuado afirmar, con Benjamin Buchloh, que «la producción de la cultura de la publicidad y el consumismo habían erosionado todos los espacios de la experiencia social anteriormente autónomos» ${ }^{12}$, haciendo que los regímenes artísticos del modernismo cayeran en la mitificación de la experiencia estética a partir de la defensa de la autonomía de sus objetos, lo cierto es que la inclusión del imaginario popular a través del pop art tampoco pondrá fin a tal autonomía. En el caso del pop esta ya no se sustentaba en una ontología de la imagen artística opuesta a la de las imágenes que conformarían la indus-

\footnotetext{
${ }^{11}$ Sobre las Brillo Box warholianas véase A. DANTO, Después del fin del arte. El arte contemporáneo y el linde de la historia, Barcelona, 1999, especialmente los capítulos «Introducción: moderno, posmoderno y contemporáneo» (pp. 25-41) y «Arte pop y futuro pasado» (pp. 141-156).

${ }^{12}$ B. BUCHLOH, Art. cit., p. 27.
} 
tria cultural, sino que las obras adquirían su aura a partir de la pertenencia a los espacios institucionales y el mercado del arte y a una nueva exaltación romántica del mito del artista, que contribuía a consolidar lo que podríamos denominar un "concepto social del arte» heredero de tal tradición romántica.

Precisamente la figura de Andy Warhol, el artista que mejor supo tematizar las veleidades ególatras de la fama y el dinero, es la que suele concitar este tipo de interpretaciones y la que contribuyó a generar parodias desmitificadoras que no siempre han surtido los efectos deseados. Ya con anterioridad a la consagración de Warhol el artista italiano Piero Manzoni ironizó sobre esta cuestión. Mediante la presentación de un envase común que contenía una cantidad determinada de excrementos del artista, este subrayaba la naturaleza comercial que su gesto procuraba a cualquier objeto señalado, invirtiendo radicalmente el impulso dadaísta que denunciaba la exclusividad de los objetos artísticos tradicionalmente asociados a los géneros pictórico o escultórico. El señalamiento de herencia duchampiana había quedado neutralizado por la visión deificada del creador y la reducción del objeto cualquiera, cotidiano y común, a mercancía.

El pop art también encontrará su cumplida réplica en contextos donde la situación económica y política no posibilitaba celebración alguna de la sociedad de consumo. En este sentido, destacaré a continuación las propuestas de dos artistas latinoamericanos, Antonio Caro y Cildo Meireles, que comparten como táctica la apropiación respectiva del logos y el envase de una marca emblemática del poder económico de Estados Unidos: Coca-Cola.

El colombiano Antonio Caro hibridó en su grabado Colombia la tipografía del logo de Coca-Cola y el nombre de su país, con la intención de alegorizar la sumisión del mismo a los intereses del capital norteamericano. Si bien en un primer momento esta estrategia puede concitar la atención del espectador, lo cierto es que, según ha señalado Edward Lucie-Smith, «lo que está siendo satirizado por lo general acaba por vencer al satírico. La imagen imitativa no hace más que aumentar la fuerza del original y grabarla con más firmeza aún en la conciencia del espectador ${ }^{13}$.

Mucho más sugerentes resultan las propuestas del brasileño Cildo Meireles, quien dentro de su investigación titulada «Inserción en circuitos ideológicos», concibió el Projeto Coca-Cola (Lám. 2). Este se presentaba como un intento de insertar contra-información en un objeto comercial. Mientras la apropiación desinteresada y aséptica de las Brillo Box por Andy Warhol suscitaba la pregunta por la naturaleza del arte, Meireles se encontraba por el contrario más interesado en la posibilidad de incidencia sobre un contexto específico, para lo que se sirvió también de un objeto real, en este caso las botellas de Coca-Cola, pero no para situarlo en el espacio de la galería con el fin de estimular la reflexión contemplativa, sino para intervenirlo antes de devolverlo a los circuitos de distribución y circulación ordinarios; en definitiva, el artista planteaba una auténtica inversión del readymade. Meireles sobreimpresionaba en las botellas el mensaje "YANKEES GO HOME», que aludía a la relación del capital comercial con el mantenimiento del poder mediante la técnica de la guerra en Vietnam, al tiempo que condenaba la dictadura brasileña sostenida por el apoyo estadounidense. Por otra parte, el proyecto contemplaba la posibilidad de que el consumidor pudiera modificar el contenido de los mensajes del envase antes de devolverlo a

\footnotetext{
-

${ }^{13}$ E. LUCIE-SMITH, Arte latinoamericano del siglo XX, Barcelona, 1994, p. 179.
} 
la circulación, con lo que se incentivaba la acción y no solo la asunción de contenidos ya predefinidos por el artista. Las calcomanías eran realizadas con tinta blanca vitrificada, solo legible cuando la botella estaba llena, lo que favorecía la no detección de las proclamas.

Las Inserciones en circuitos ideológicos incluían también otra iniciativa desde la que se puede establecer un diálogo con alguna de las imágenes warholianas. Me refiero al Proyecto Cédula. El interés por el dinero que en Warhol conducirá a la conversión estética del valor de cambio de los billetes de un dólar mediante su representación como parte de una serie pictórica que acababa por conformar una unidad, en Meireles se reorientará nuevamente hacia la intervención directa sobre los billetes que circulan diariamente regulando los intercambios económicos. El artista recurrirá en esta ocasión a un matasellos con el que imprimirá sobre los billetes consignas como «¿Quién mató a Herzog?» - aserto que se popularizó como una alusión a la tortura y posterior asesinato de ese periodista por la dictadura militar $-\mathrm{u}$ otros mensajes que incitaban a la inserción de «informaciones $\mathrm{u}$ opiniones críticas» antes de ser devueltos a la circulación.

\section{EL CONCEPTUALISMO EN EL ESPACIO URBANO: HIANCIAS INTERROGATIVAS}

Redimensionando el ámbito de influencia del arte moderno, el conceptualismo tratará de validar su posición crítica a partir de propuestas que, insertadas en espacios no habituales, cortocircuiten a modo de paréntesis o cesura la proliferación inusitada de los signos publicitarios en las ciudades contemporáneas. Esta omnipresencia sígnica aparece unida a una lógica de la comunicación basada en la transparencia del lenguaje, cuya posibilidad ya fuera cuestionada por artistas como Mel Bochner.
En sus proyectos más ambiciosos los artistas se plantearán incluso la posibilidad de interrumpir los flujos de información de los medios masivos de comunicación. El diálogo con el entorno expositivo o urbano dará lugar, progresivamente, a la aparición de una nueva tipología artística, la intervención, que no era posible catalogar bajo los géneros tradicionales de la pintura, la escultura o la arquitectura. He decidido denominar a estos paréntesis sígnicos, a menudo lingüísticos, con un término tomado del vocabulario psicoanalítico: «hiancia» es el lugar de la antinomia del discurso, de la contradicción, de la diferencia; en definitiva, de la posibilidad de apertura de todo debate. Para generar esas interrupciones los artistas recurrirán a estrategias que irán desde la autorreferencialidad extrema a la apelación directa a la reflexión del viandante.

Parece lógico que estas prácticas se presentaran con especial prontitud y notable relevancia, al hilo de la revisión del arte pop que acabo de mencionar, en aquellas latitudes geográficas cuya situación sociopolítica era más agitada y donde la industria cultural, a diferencia de lo sucedido en los países más desarrollados, estaba en plena expansión.

En Argentina, los soportes urbanos de la publicidad habían sido tempranamente invadidos por artistas como Alberto Greco - que insertó proclamas autoparódicas del tipo «iGreco, qué grande sos!»- o por el auge del entusiasta e ingenuo pop porteño. Desde el año 1965 estas primeras tentativas fueron sucedidas por una original línea de trabajo que aunó la labor de artistas, sociólogos, filósofos y periodistas: el llamado «arte de los medios», que partió de una lectura crítica de la tesis mcluhaniana en torno a la identidad entre medio y mensaje, promovió experiencias como Happening para un jabalí difunto, en el que un periódico de tirada nacional difundió un re- 
portaje sobre un happening jamás realizado, revelando así el modo en que los medios, lejos de reflejar la realidad, la construyen.

Una de las intervenciones más conocidas del grupo fue la llevada a cabo por Óscar Masotta, verdadero ideólogo del mismo, quien en Mensaje fantasma (Lám. 3) ideó una suerte de tautología mediática que establecía un circuito cerrado entre la información que el viandante leía en un cartel publicitario y la que posteriormente recibía por televisión. El referido cartel constaba de un mensaje, «Este afiche aparecerá proyectado por canal 11 de televisión el día 20 de julio», que remitía a una emisión televisiva en la que el locutor anunciaba la aparición de un «afiche» en la ciudad. Tras la noticia, en el siguiente plano se reproducía con una tipografía diferente el texto del panel publicitario de la trama urbana ${ }^{14}$. Este circuito cerrado de información se opondría a la condición referencial de la publicidad comercial, siempre orientada hacia el objeto de deseo, señalando por el contrario la propia materialidad del medio en que el mensaje se insertaba ${ }^{15}$.

El sentido crítico de las prácticas latinoamericanas ha querido ser leído por la historiografía reciente de los países de aquel ámbito como un preludio de las prácticas llevadas a cabo por artistas de los países centrales durante los años 70 y $80^{16}$, sin que ello exija una filiación directa entre

\footnotetext{
${ }^{14}$ Una descripción más minuciosa de la obra puede encontrarse en J. LÓPEZ ANAYA, Arte argentino. Cuatro siglos de historia (1600-2000), Buenos Aires, 2005, pp. 433-434.

${ }^{15}$ Para esta y otras cuestiones relativas a la obra de Masotta, consúltese el estudio de A. LONGONI, «Vanguardia y revolución en los sesenta», Revolución en el arte. Pop art, happenings y arte de los medios en la década del sesenta, Buenos Aires, 2004, pp. 9-105.

${ }^{16}$ Mari Carmen Ramírez destaca este punto en M. C. RAMÍREZ «Tactics for Thriving on Adversity: Conceptualism in Latin America, 1960-1980», Global Conceptualism: Points of Origin, 1950s-1980s, Nueva York, 1999, pp. 53-71.
}

las prácticas de unos y otros, cuya relación proviene, más bien, de la exigencia de demandar presencia política ante los diferentes retos que planteaban sus sociedades respectivas.

En todo caso, antes de abordar las obras de esos artistas norteamericanos y europeos, es necesario apuntar mínimamente el contexto relativo a la historia del arte que heredan del arte conceptual, cuyos planteamientos serán revisados a la hora de plantear contradiscursos que pusieran en jaque los desplegados por el lenguaje publicitario.

Con frecuencia, las diversas genealogías del arte conceptual se suelen articular - ya sea para relatar sus desarrollos, ya para marcar sus diferencias - a partir de planteamientos tautológicos como los de Joseph Kosuth. En algunas de sus proposiciones, el artista norteamericano empleó un material tan presente en el entorno publicitario urbano como el neón, cuya luminosidad, destinada a captar la atención del espectador, se veía relegada a ser soporte de un enunciado de contenido completamente autorreferencial $^{17}$. Una tentativa que encontrará cumplida réplica en una obra posterior de Bruce Nauman, One Hundred Live and Die (1984), en la que los neones recogían pares de palabras dispuestas en diversas combinaciones que lejos de configurar un significado referencial o una tautología, tendían a la distorsión y el sinsentido.

Celosos de los espacios expositivos, que dotaban a priori sus propuestas de una plusvalía institucional, los artistas conceptuales comenzaron a buscar otras alternativas para insertar sus mensajes. Entre ellas cabe destacar la prensa - en tanto instrumento por antonomasia del poder burgués en la conformación y reflejo de la opinión

\footnotetext{
${ }^{17}$ Así sucede, por ejemplo, en Four Words Four Colors, de 1965.
} 
pública - y los paneles publicitarios de la trama urbana. Así, el propio Joseph Kosuth o Dan Graham ocuparon el espacio de los periódicos habitualmente destinado a los anuncios para insertar proposiciones que captaran la atención del lector, por lo general distraída, errante, al consultar esas secciones. Joseph Kosuth lo hizo mediante la presentación de sinopsis de categorías que tanto por su limpieza tipográfica como por su sistematicidad reclamaban la atención del lector acerca de cuestiones de diversa índole, como la comunicación de ideas o el lenguaje escrito. En el caso de Dan Graham, el artista insertó un recibo de la compra en un número de la revista Harper's Bazaar, justamente entre un anuncio de tampones y otro de sujetadores (Lám. 4). La banalidad del registro de una tarea doméstica en un intersticio del espacio publicitario pretendía generar en el lector un extrañamiento o dépaysement que le invitara a reflexionar sobre las estampas profilácticas y eróticas de los anuncios que lo rodeaban.

La extrema autorreferencialidad de las tautologías kosuthianas podría ser interpretada, por otra parte, como la clausura o cancelación de la autonomía de la obra de arte. Constatando la imposibilidad de construir significados ajenos al entorno en que se exhibe, la obra pasaba a presentarse a modo de señuelo o índice negativo destinado a disparar la reflexión acerca de cómo se originan aquellos en su contexto específi$\mathrm{CO}^{18}$. Según destacara recientemente el artista, «con la sucesiva «opacidad» del lenguaje tradicional del arte (pintura y escultura) en los años sesenta, los objetos mismos (pinturas y esculturas) comenzaron a perder

\footnotetext{
${ }^{18}$ En este sentido, la producción textual del artista se situaría en el mismo plano que (y no como explicación o crítica de) la obra, cuya entidad tiende a difuminarse. Nos encontraríamos ante el tránsito de la obra al texto descrito por R. BARTHES en «De la obra al texto», El susurro del lenguaje. Más allá de la palabra y de la escritura, Barcelona, 1987, pp. 73-82.
}

«credibilidad» (el lenguaje estaba perdiendo su transparencia). Se estaba siempre «fuera» de la obra y nunca en su «interior». Es por ello que, a lo largo de los años sesenta, se empezó a desplazar en medida creciente la orientación desde el objeto «increíble» a aquello que era creíble y real: el contexto» ${ }^{19}$. Además del trabajo sobre el concepto de arte, el artista se planteó el reto de pensar la función del arte en el espacio urbano. Por ello insertó alguna de sus investigaciones en paneles publicitarios que establecían una relación dialéctica con otros ocupados por anuncios, tal y como se puede apreciar en The Seventh Investigation (Art as Idea as Idea) (1969), donde junto a un anuncio de una conocida marca de whisky el artista desplegó un cartel que reproducía un extracto de un libro de psicología relativo a las funciones mentales del ser humano.

Esa cancelación de la autonomía de la obra como paso previo a su interacción contextual hizo proliferar todas aquellas poéticas que suelen aparecer vinculadas por la noción de «campo expandido» ${ }^{20}$, relativa al modo en que esas prácticas cuestionaron tanto la naturaleza objetual como los márgenes institucionales del arte moderno. Dentro de ese epígrafe, artistas como Daniel Buren pensaron su actividad nuevamente en términos negativos, en el sentido de que sus creaciones debían definirse por lo que no eran, aproximándose a lo que la crítica ha dado en llamar «el grado cero de la pintura». La literatura del artista manifestaba una postura anti-arte, ya que este, en cualquiera de sus formas, sería reaccionario. Sus no-pinturas, pegadas en los soportes urbanos o movilizadas por

\footnotetext{
19 J. Kosuth, «Senza uscita», «Modus Operandi» Cancellato, Rovesciato. Un'opera di Joseph Kosuth al Museo di Capodimonte, Nápoles, 1998, p. 16.

${ }^{20}$ Véase R. KRAUSS, «La escultura en el campo expandido", La originalidad de la vanguardia y otros mitos modernos, Madrid, 1996, pp. 289-303.
} 
hombres-anuncio no eran publicidad, pero tampoco arte.

La no referencialidad y la repetición sistemática del motivo de las bandas de colores de Buren (quien siguió, en este aspecto, una estrategia consensuada con Olivier Mosset, Michel Parmentier y Niele Toroni, integrantes del grupo BMPT (Lám. 5) contrastaba con la comunicabilidad y la novedad publicitarias, al tiempo que trataba de cuestionar radicalmente la idea de originalidad vinculada al artista de vanguardia. Este gesto de cesura respondía a un contexto sociopolítico muy determinado, que estalló en el mayo del 68 francés. El hecho de que desde entonces el artista haya seguido recurriendo a ese mismo motivo, de manera sumamente formalista, ha relegado lo que era un gesto radical a una imagen de marca, al modo de las que sellan estéticamente los productos comerciales. El interés por la transformación de los espacios arquitectónicos, aún detectable en la intervención realizada en el Palais Royal de París, ha dejado paso al espíritu estrictamente decorativo, según se puede apreciar en proyectos como el realizado recientemente en Lugano para la BSI Art Collection $^{21}$.

El carácter intersticial y negativo de estas intervenciones en el espacio urbano encontró su representación más ejemplar en la City Performance desarrollada por Tania Mouraud en las calles de París durante 1978 (Lám. 6). En una intervención que podríamos situar entre las denominadas poéticas posmodernas del «entre», la artista compró un espacio publicitario para insertar en él un significativo «NI». El lenguaje del arte quedaba así reducido a la negación del universo simbólico que lo circundaba.

${ }^{21}$ Para un análisis más detallado de la trayectoria del artista, consúltese J. HernANDO CARRASCO, Daniel Buren. La postpintura en el campo expandido, Murcia, 2007 y G. Lelong, Daniel Buren, Paris, 2001.
Por su parte, artistas más recientes como Félix González Torres o Alfredo Jaar han intentado captar la atención del espectador mediante nuevas estrategias que revisan esa negatividad, conciliando el carácter intersticial heredero del primer conceptualismo con el abordaje de cuestiones de índole social o política en el espacio urbano, retomando de ese modo las propuestas del arte crítico de los años setenta, que analizaré en el siguiente punto. La tematización de los nuevos problemas suele realizarse de modo tangencial por razones que, en los dos ejemplos que planteo a continuación, responden al deseo de evitar el tratamiento sensacionalista de la enfermedad y a la imposibilidad de plasmar en imágenes un conflicto étnico-político.

González Torres dispuso sobre un panel publicitario la imagen de una cama vacía sin ningún acompañamiento textual, estableciendo un juego entre ausencia y presencia que invitaba al espectador a completar un significado que, si bien podía ser asociado a la reciente muerte de su amante como consecuencia del SIDA, en ningún caso era prescriptivo. Por su parte, Alfredo Jaar ha centrado su atención en el genocidio ruandés del año 94 (Lám. 7). En los paneles vidriados de diversas ciudades occidentales, Jaar introdujo una composición tipográfica con el nombre de aquel país como un modo de atestiguar dentro del debate contemporáneo en torno a la validez de las imágenes para mostrar lo real-traumático, su posición negativa ${ }^{22}$. La

\footnotetext{
${ }^{22}$ Una síntesis de este debate y el cuestionamiento de la tesis negativista pueden leerse en G. DIDI HuBERMAN, Imágenes pese a todo, Barcelona, 2004. Según hemos visto, cabría distinguir, al menos, tres negatividades en el arte de posguerra: una negatividad ontológica ligada a la autonomía modernista y destinada a desvelar la esencia del medio; una negatividad indicial que, característica de algunos planteamientos conceptuales, renuncia al hallazgo de una ontología de la obra para apuntar hacia el contexto en que interviene; $y$, finalmente, una negatividad ética, relacionada
} 
palabra aparece entonces como testimonio sublime de la impotencia de la imagen para la representación de la tragedia, alertando además de la falacia informativa a propósito del conflicto ruandés, presentado como una disputa étnica que borraba su vertiente estrictamente política, detectable tanto en la implicación histórica de la antigua colonizadora, Bélgica, como en la injerencia contemporánea de Francia, sumamente atenta a mantener su zona de influencia frente a la incursión de la anglophonie ${ }^{23}$.

\section{PRÁCTICAS DE RESISTENCIA: ARTE CRÍTICO Y PUBLICIDAD. ALGUNAS FI- GURAS PARADIGMÁTICAS}

Como dije anteriormente, estas últimas experiencias deben relacionarse con algunas de los prácticas que surgieron durante la década de los 70 y principios de los años 80, cuando diversos artistas se plantearon la posibilidad de reorientar la reflexión lingüística que acompañaba a las primeras prácticas conceptuales hacia una incidencia más inmediata y directa en el paisaje social. Estos artistas renunciaron en consecuencia a la negatividad con la esperanza de conformar lo que se ha dado en denominar un arte crítico, que según los casos presentó sus propuestas en el espacio público de la ciudad o en el de la institución arte. La posibilidad de ubicar estas prácticas bajo la etiqueta de postconceptuales deriva del hecho de que lejos de constituir un estilo histórico con características formales específicas, el conceptualismo se define por su voluntad interrogativa ${ }^{24}$, así como por la apertura del concepto de arte

con la imposibilidad de representar el terror -ya sea el Holocausto o, en este caso, el genocidio ruandés-.

${ }^{23}$ Véase A. JAAR, Hágase la luz. Proyecto Ruanda 1994-1998, Barcelona, 1999. Sobre la génesis y desarrollo del conflicto resulta sumamente reveladora la crónica de R. KAPUSCINSKI, «Conferencia sobre Ruanda», Ébano, Barcelona, 1998, pp. 177-194.

${ }^{24}$ T. GODFREY, Ob. cit., p. 424. hacia sucesivas reformulaciones que le permitan adaptarse y dar respuesta a los problemas planteados por cada contexto sociocultural. Entre los artistas que, dentro de los países «centrales», pueden ser ubicados en el seno de la órbita postconceptual, suelen destacarse figuras como Martha Rosler, Jenny Holzer, Barbara Kruger, Victor Burgin, Hans Haacke, Cindy Sherman o Richard Prince, de los que me ocuparé brevemente a continuación.

Martha Rosler planteó tempranamente diversas series de «fotomontajes críticos», entre las que sobresalen Body Beautiful, or Beauty Knows No Pain, iniciada en $1965 \mathrm{y}$, sobre todo la inmediatamente posterior Bringing the War Home (1966-1972). En la primera de ellas se cuestionaba el papel de la mujer tanto en el ámbito doméstico como en lo referente a la sexualidad. El procedimiento seguido por la artista consistía en superponer o alterar algunos anuncios con la intención de hacer aflorar la situación de opresión sufrida por el sexo femenino. Rosler forma parte de un grupo numeroso de artistas que se revolverán contra el estereotipo machista que la imagen publicitaria plasma de la mujer, un estereotipo heredero de los modelos renacentistas que conferían a la sexualidad un carácter superficial pensado a la medida del mirón o voyeur.

En Bringing the War Home, la segunda de las series citadas, Rosler abordaba la temática en torno a la cual confluyeron, según destaqué más arriba, buena parte de las propuestas artísticas críticas de la época: la guerra de Vietnam. Este acontecimiento fue decisivo para artistas como Rosler a la hora de abandonar la pintura como medio de expresión. Los fotomontajes de Rosler mostraban interiores de la clase acomodada en los que irrumpían estampas del conflicto vietnamita. Esos espacios cotidianos, que evocaban claramente las imágenes de las revistas de interiorismo y decoración, eran 
subvertidos desde distintas ópticas, incluida la crítica corrosiva a la deriva del movimiento arquitectónico moderno (Lám. 8). La transparencia de sus arquitecturas, su pretensión de difuminar los límites entre los espacios público y privado, se veían comprometidos por la pregunta acerca de qué es lo que se ve, constatando la estetización en que habían caído tales modelos arquitectónicos en una sociedad que mantenía las mismas reglas del juego.

A diferencia de las primeras imágenes pop, a medio camino entre la celebración y la parodia de los espacios interiores de la vida cotidiana - según sintetizara Richard Hamilton en su collage inaugural ¿Qué es lo que hace los hogares de hoy tan diferentes, tan atractivos? - los fotomontajes de Rosler, deudores de las experiencia alemana de entreguerras de fotógrafos como John Heartfield, subvertían la imagen paradisíaca de la publicidad poniendo en tela de juicio la pretensión del sistema de situar el conflicto en un horizonte espacial lejano. Rosler recurría así al montaje siguiendo una estrategia de dislocación del sentido inscrita dentro de la tradición artística marxista de crítica política, en la que el cine soviético, con Eisenstein y Vertov a la cabeza, ocupa un lugar fundamental.

Tras esta primera tentativa y el acercamiento progresivo a los hallazgos del arte conceptual, Rosler incluirá la palabra en sus imágenes de denuncia, a menudo con la pretensión de cuestionar la insuficiencia de la fotografía como documento, distanciándose así de su interés inicial por la obra de Walker Evans. Este aspecto de su trabajo se manifestaba explícitamente en el título de The Bowery in Two Inadequate Descriptive Systems (1974-75), un sucinto análisis sociourbano donde fotografía y palabra se confrontaban de modo dialéctico. The Bowe$r y$, cuyo título remite a uno de los barrios más desfavorecidos de Nueva York, presentaba una serie de imágenes desnudas de la presencia humana cuya aparente neutralidad documental era quebrada por las palabras de los encuadres de la derecha, alusivas a problemáticas específicas de ese lugar como el alcoholismo.

The Bowery se vislumbra como una obra de referencia que ha encontrado continuidad en trabajos posteriores de la artista y de otros creadores. En su serie In the Place of the Public: Airport Series, iniciada en 1983, Rosler ha reflexionado en torno al que considera uno de los espacios postmodernos por excelencia: los aeropuertos. Las fotografías que la artista ha ido recopilando recogen diversos aspectos de los espacios publicitarios, pasillos, salas de espera o interiores de aviones y se presentan acompañadas de elementos textuales que, según ha explicado Alexander Alberro, responden a dos motivos diversos: «las frases y expresiones colocadas en la pared, cerca de las fotografías, desarrollan una imagen fenomenológica de la transición a través de los aviones y aeropuertos [mientras que] a lo largo del suelo hay una lista de instituciones y estructuras más tradicionales, mediante las cuales hemos marcado nuestra vida colectiva ${ }^{25}$, que van desde un árbol a un libro, pasando por un templo o un prostíbulo ${ }^{26}$.

Durante los años 80, Rosler orientará algunas de sus producciones hacia el análisis desmitificador de los media, tal y como sucedía en Mith Today: Edited for Televisión

\footnotetext{
${ }^{25}$ A. ALBERRO, «La dialéctica de la vida cotidiana: Martha Rosler y la estrategia del señuelo», Martha Rosler: posiciones en el mundo real, Barcelona, 2000, pp. 110 y 111

${ }^{26}$ Matt Siber, en un trabajo reciente (Sin título, 2000), ha empleado un recurso similar con la intención de cuestionar la aparente transparencia del lenguaje publicitario, basada en la comunión entre imagen y texto. La parte textual de la publicidad urbana es extirpada y reinsertada en una estampa anexa, conservando tanto el lugar que le correspondería de ser superpuesta sobre la fotografía tomada como la tipografía original.
} 
$(1985)^{27}$, que presentaba la novedad de disponerse en un espacio publicitario urbano. Con un título tomado directamente de uno de los ensayos de Roland Barthes que conforman su libro Mitologías (1957), Myth Today afirmaba la condición mítica de medios de masas como la televisión. Para la artista, dicha condición residiría menos en los contenidos que transmiten esos medios que en su propia constitución formal como sistemas de comunicación.

Sin embargo, la artista que quizás con más asiduidad ha transitado los espacios urbanos, habitualmente colapsados por la publicidad, ha sido Jenny Holzer. En competencia con las estrategias propias del marketing, Holzer persigue en sus obras ejercer sobre el espectador una influencia similar pero de sentido inverso. A diferencia de lo que había sucedido con la primera hornada de artistas conceptuales, la artista recurrió a las tecnologías propias de la sociedad del espectáculo para introducir en ellas sus planteamientos disruptivos. Una de sus primeras series, Truisms (Verismos), consistía en diversos mensajes textuales que se presentaban en distintos formatos, entre ellos posters pegados sobre muros o enunciados en grandes paneles electrónicos situados en las fachadas de diferentes edificios de Manhattan. Muchos de esos mensajes consistían en «declaraciones didácticas o de opinión», tales como "UNA ACTITUD POSITIVA MARCA LA DIFERENCIA» $\mathrm{O}$ «RECUERDA QUE SIEMPRE TIENES LIBERTAD DE ELECCIÓN» sobre los que se extendía la sospecha de la uniformidad ideológica de la opinión pública ${ }^{28}$.

\footnotetext{
${ }^{27}$ Myth Today fue en realidad la alternativa que la artista propuso ante la cancelación de su proyecto de carteles publicitarios para la ciudad de Minneapolis Relax, No Enemy Foot Steps Here, en la que denunciaba que tanto esa ciudad como St. Paul tenían prohibido el acceso a los rusos.

${ }^{28}$ En lo que se antoja como una elaboración estética de la cita heideggeriana: ««Distanciación», «término
}

Incluso en el caso de los enunciados aparentemente más subversivos, estos no eran sino tópicos desarticulados que, al irrumpir en un espacio y soporte no habituales, desvelaban la naturaleza consensual y arbitraria de la opinión pública, tendente a coincidir con las voces procedentes de la propaganda gubernamental y de la publicidad. De esta manera, la artista pretendía enfrentar al viandante a la precariedad de su presencia como sujeto democrático. Además del efecto producido por cada una de esas proclamas, el conjunto de las mismas constataba el sentido contradictorio y por tanto alienante de las proposiciones que lo conformaban.

Holzer dio continuidad a esta línea de trabajo a comienzos de los 80 en una nueva serie de eslóganes en las pantallas de Times Square, donde se exhibieron enunciados alusivos a la aceptación de los mecanismos del poder («EL ABUSO DE PODER DEVIENE NO SORPRENDENTE») o a la correspondencia entre lo estético y lo crematístico («EL DINERO CREA EL GUSTO»).

Dejando a un lado la denuncia de la ambigüedad ideológica de los lugares comunes, otros textos de Holzer preferían apelar a las emociones del espectador antes que a su intelecto, marcando así una cierta distancia con la frialdad y la asepsia características del primer arte conceptual. Es el caso de «PROTÉGEME DE LO QUE QUIERO» (Lám. 9), un enunciado sumamente

medio», «aplanamiento» constituyen, en cuanto modos del ser del «uno», lo que designamos como «opinión pública». Ésta es lo que regula inmediatamente toda interpretación del mundo (...) y tiene en todo razón. $\mathrm{Y}$ no porque posea una señalada y primaria «relación de ser» con las «cosas» (...), sino justo por no entrar «en el fondo de los asuntos», por ser insensible a todas las diferencias de nivel y de autenticidad. La opinión pública lo oscurece todo y da lo así encubierto por lo sabido y accesible a todos», en: M. HEIDEGGER, El ser y el tiempo, México D.F., 1951, p. 144. 
sugestivo que implicaba la subjetividad del espectador como sujeto del deseo autofrustrado, alienado tal vez por las promesas irreales de la publicidad.

Por otra parte, la artista se distanciaba de utopías como la de Sol Lewitt, quien afirmara en uno de sus «Parágrafos sobre arte conceptual» su deseo de transmitir las ideas de modo telepático ${ }^{29}$, y se preocupaba más, por así decirlo, del modo material en que estas se exponen. En su trabajo se constata la imposibilidad de disociar el contenido del texto de los aspectos tipográficos o lumínicos, así como de la incidencia sobre la arquitectura y el contexto en que se insertan. En opinión de Söke Dinkla, las imágenes-texto de Holzer se aproximan al ideal de un lenguaje entendido como fusión de imagen y significado ${ }^{30}$.

Esta coalición entre texto e imagen cobrará aún mayor relevancia en la serie de proyecciones Xenon. En ellas, la impronta de la imagen sobre los edificios relega la lectura de los mensajes a un segundo momento. La alteración visual del lugar sobre el que estos se proyectan es el motivo predominante. Dicha visualidad contrarresta el componente arquitectónico hasta el punto de que en algunos casos los edificios adquieren un aire fantasmagórico, que podría interpretarse como una desmaterialización o virtualización de la arquitectura, un aspecto que ha suscitado diversas críticas acerca de la deriva espectacular de los últimos proyectos de la artista.

29 «La obra de arte se puede entender como un hilo conductor que va de la mente del artista a la del espectador. Pero puede suceder que no llegue nunca al espectador, o que no salga de la mente del artista», S. LEWITT, «Parágrafos sobre arte conceptual», Seis años: la desmaterialización del objeto artístico de 1966 a 1972, Tres Cantos, 2004, p. 125.

${ }^{30}$ Véase S. DINKLA, «Signatures of memory», Jenny Holzer. Die Macht des Wortes. I can't tell you, Ostfildern-Ruit, 2006, p. 25.
Es este un procedimiento, el de las proyecciones, también empleado por la publicidad. La diferencia en la propuesta de la artista estriba en la ambigüedad del significado y en la disposición de los textos. Estos, durante el transcurso de los años, han tendido a mantener más abierto su sentido o a dejar inconclusos los enunciados, una estrategia que incitaría al espectador a completarlos. Frente a la temporalidad de la comprensión de los textos de Holzer, la publicidad trataría de traspasar a toda velocidad el umbral de la conciencia para activar de manera inmediata los mecanismos del deseo y la posesión.

El carácter secuencial de las obras de Holzer debe mucho a la idea de montaje. Según resalta Dinkla, al contrario de los planteamientos futuristas, la condición sintáctica de las imágenes - texto de Holzer no persigue «deconstruir las palabras, sino disponerlas en un montaje que pueda ser experimentado en su dimensión temporal durante el acto de lectura» ${ }^{31}$. En las imágenes de la artista se establece un juego entre ausencia y presencia, entre lo que vemos y lo que nos sugiere lo que vemos, que trataría de deconstruir las ideologías soterradas bajo la falsa transparencia de la publicidad y los medios que la difunden.

Barbara Kruger, por su parte, también concebirá la calle como su lugar de intervención. Para ella resulta fundamental la posibilidad de poner en cuestión la aparente sintonía entre imagen y texto en los anuncios publicitarios. Con esta intención emplea la imagen como instrumento captador de la mirada, que incite en segunda instancia a la lectura del texto. Entre las diversas imágenes generadas por la artista, me parece especialmente relevante, dadas sus resonancias filosóficas, I shop therefore I am (1987). En ella, Kruger impugna la tota-

\footnotetext{
${ }^{31}$ Véase Ibid., pp. $26-27$.
} 
lidad del proyecto ilustrado ante la constatación de que la metafísica cartesiana del «Pienso, luego existo» encuentra hoy en día su réplica subjetivista en la obstinación del individuo en autoafirmarse mediante el consumo.

Sin embargo, Kruger es más conocida por sus obras de corte feminista. En este ámbito, la artista apostaría por la consideración del cuerpo femenino en términos de "campo de batalla» (Your body is a battleground, 1989) y no como modelo de belleza. Kruger subrayaba la necesidad de que la mujer abandonara su rol progenitor tradicional, reclamando derechos legales para el aborto y el control de la natalidad. La imagen fue concebida para ser empleada durante las marchas que tuvieron lugar en Washington en 1989 contra la administración Bush y fue posteriormente reutilizada por colectivos feministas de otros países.

Las rupturistas imágenes de Kruger, sin embargo, no siempre han cumplido su cometido. A propósito de esta cuestión, Donald Kuspit, desde una posición imbuida por lo demás de nostalgias neogreenbergianas, ha señalado el fracaso de estos intentos de socialización de la obra de arte. En palabras del crítico norteamericano, «el «Yo soy porque compro» de Kruger se entendió como la afirmación de un hecho, no como una réplica irónica». Para justificar este afirmación, Kuspit señala que el aserto se reprodujo en bolsas de la compra, testificando así la autoconsciencia del consumidor ${ }^{32}$.

En una línea de trabajo similar a la de Kruger, la relación que se establece en el ámbito de la publicidad o de la cartelística urbana entre imagen y palabra ha seguido siendo explorada más recientemente por artistas como Rogelio López Cuenca. Para

\footnotetext{
${ }^{32}$ Véase D. KUSPIT, El fin del arte, Madrid, 2006, p. 83.
}

López Cuenca lo textual se presenta como un elemento de resistencia frente al poder omnímodo de lo visual, del que hace gala el medio publicitario. En palabras del artista, «expresiones de irrefutabilidad como «prueba ocular» o «testimonio visual» dan una idea del poder de la visión en nuestra

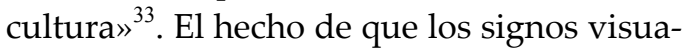
les que pueblan la publicidad sean fruto de un código cuya lectura se reduce a un número de especialistas, entre los que sobresalen los semiólogos, implica que el artista haya de introducir la palabra como elemento retardatario de la comprensión del sentido, una idea que debe mucho a Duchamp y que se encuentra encaminada hacia la activación reflexiva del espectador. El trabajo de López Cuenca, generalmente caracterizado bajo el término de «contrapublicidad», ha sabido insertar en el espacio urbano mensajes que tratan de revertir la simplicidad y el automatismo de los eslóganes publicitarios en enunciados con una carga política cuya relación con el contexto en que se ubican es más específica que en el caso de Kruger. Destacaré únicamente una obra que me resultó especialmente sugerente y que formó parte del proyecto «Calle Cavafis», pensado a propósito del II Coloquio sobre Grecia organizado por la Universidad de Málaga en el año 1998 (Lám. 10). En una de sus intervenciones, el artista dispuso en un panel publicitario el poema de Constantin Cavafis «El dios abandona a Antonio». El poema aparecía impreso sobre una fotografía que, teñida por los colores de la bandera de la II República, registraba un acto de 1931 ante la cruz que señala el fusilamiento de José María de Torrijos y un grupo de antiabsolutistas por las tropas de Fernando VII, ajusticiamiento del cual se cumplía el primer centenario. La cruz se encontraba situada en un barrio obrero hoy arrasado por la especulación inmobiliaria.

\footnotetext{
${ }^{33}$ R. LÓPEZ CUENCA, «Language is the lens of sight», Exit, 16, 2004, p. 74.
} 
Del mismo modo que Cavafis pedía a Antonio valentía para contemplar la procesión de instrumentos y voces que alegorizaban Alejandría y con ella la dulzura de una vida frustrada en la vanidad del deseo, López Cuenca alertaba a los malagueños ante el olvido de un tiempo de reclamo de libertades que distaba de ser una mera ensoñación $^{34}$.

Retornando a los años 70, he de señalar que no solo las artistas próximas a la órbita feminista focalizaron su atención en el papel de la publicidad y los medios de comunicación de masas. Artistas como Victor Burgin o Hans Haacke desarrollarán diversas estrategias destinadas a desvelar la relación entre publicidad, poder y arte.

En el caso de Burgin, sus primeros proyectos en el espacio urbano perseguían la confrontación directa con la ideología publicitaria recurriendo a eslóganes rotundos. Sobresale en este sentido Possession, de 1976 (Lám. 11), que el artista pensó para las calles de la localidad inglesa de Newcastle upon Tyne. Burgin obtuvo la ilustración del cartel de una biblioteca de imágenes empleada por agencias publicitarias con la intención de establecer un juego dialéctico entre el concepto de posesión que la imagen parece sugerir a partir de la lectura de la pregunta superior y el dato estadístico de la sección inferior. Burgin establecía una direccionalidad de la lectura: el signo de interrogación y la imagen captan en primera instancia la atención del espectador. De la posesión erótica y la implicación emocional de la subjetividad se pasa a la frialdad del dato estadístico extraído de una publicación especializada, en este caso el diario inglés

\footnotetext{
${ }^{34}$ Esta y otras muchas propuestas del artista aparecen contenidas en catálogos de exposición como Astilhãografo. Rogelio López Cuenca, Madrid, 2002, Obras. Rogelio López Cuenca, Granada, 2000, El Paraíso es de los extraños, Málaga, 2003 o Word\$. Rogelio López Cuenca, Sevilla, 1994.
}

The Economist. Bajo la influencia del pensamiento de Roland Barthes, Burgin defendía por esos años un «formalismo socialista» que desenmascarara las «mistificaciones de la sociedad burguesa descifrando sus códigos, exponiendo los mecanismos mediante los cuales construye su propia imagen ${ }^{35}$.

Posteriormente, la revisión del pensamiento marxista llevada a cabo por autores como Louis Althusser o Antonio Gramsci le condujeron a replantearse el modo de ejercer la crítica social. Así, el artista abogará por contenidos más sutiles e indirectos que renunciaban a plasmar una «verdad desnuda», ya que esta acababa por reforzar la ideología que trataba de combatir. Burgin dejó de insertar su obra en el espacio urbano para tratar de deslizar sus mensajes dentro del ámbito institucional, en lo que se ha interpretado como un programa de subversión sígnica, de guerrilla semiótica. Así sucedía en trabajos como US/77, obra en la que, según ha escrito Jorge Ribalta, «los textos dejan de relacionarse de una manera obvia con la imagen y abren un campo de lectura menos inmediato cuyo significado no se agota tan rápidamente sino que deja un mayor espacio para la «productividad del lector»» ${ }^{36}$, en una línea borgiana que privilegiaba el tiempo de lectura e interpretación sobre el de creación ${ }^{37}$.

De alguna manera, Burgin probablemente detectó la posibilidad de que las prácticas de artistas como Holzer o Kruger

\footnotetext{
-

${ }^{35}$ Véase S. MORLEY, Writing on the wall. Word and image in the modern art, Berkeley / Los Angeles, 2003, p. 148.

${ }^{36}$ J. RibALTA, «Encadenando teorías», Lápiz, 75, 1991, p. 74.

${ }^{37}$ El escritor argentino preludió en relatos como «Pierre Menard, autor del Quijote» (contenido en su libro Ficciones, publicado en 1944) el tránsito del autor al lector descrito por R. BARTHES en «La muerte del autor», El susurro del lenguaje. Más allá de la palabra y la escritura, Barcelona, 1987, pp. 65-71.
} 
adquirieran una deriva espectacular que acabara por afirmar su objeto de crítica, a modo de lo que Donald Kuspit ha denominado como «teatro social» ${ }^{38}$. Si este mismo crítico ha señalado que el rasgo principal del arte posmoderno es su desinterés por el inconsciente en beneficio del consenso semántico social, lo cierto es que precisamente Burgin desarrollará una labor teórica que, en textos como «Ver el sentido», leerá en clave psicoanalítica los anuncios publicitarios $^{39}$. La ambigüedad significativa que se establece en la relación entre imagen y texto en algunos de los trabajos que el artista realiza por esa época parece evocar dicha hermenéutica publicitaria. Uno de esos ejemplos, presentado en un formato publicitario, será A Promise of Tradition, donde el artista presenta irónicamente, mediante una serie de sentencias cortas superpuestas sobre una fotografía, la «promesa de tradición» y el carácter excluyente de las clases enriquecidas.

En todo caso, el artista que, en relación con el tema de la publicidad, tal vez haya desarrollado un trabajo más constante a la hora de desvelar la confabulación entre poder, imagen corporativa e institución arte es Hans Haacke. A diferencia de Holzer, Kruger o López Cuenca, Haacke optó generalmente por infiltrar su obra en el espacio del museo o la institución.

Como es sabido, el museo debe su fundación a la voluntad burguesa postrevolucionaria de instituir un espacio público de contemplación estética que se opusiera al carácter estrictamente privado de las colecciones reales. Así, el 10 de agosto de 1793 se inauguraba el Museo de la República francesa en el palacio del Louvre. Desde los años 60 del siglo XX han sido numerosos los debates en torno a la posibilidad de

\footnotetext{
${ }^{38}$ D. KUSPIT, Ob. cit., p. 82.

${ }^{39}$ Véase V. Burgin, Art. Cit.
}

emitir juicios críticos desde el espacio del museo, en la medida en que este no se liberara de su condición burguesa. Una posición que a veces desestima que el supuesto espacio abierto de la ciudad se encuentra habitualmente tan expuesto a los signos de ese poder como el espacio cerrado de los museos. No en vano se ha hablado de un proceso contemporáneo de museificación de las ciudades, cuando no de la naturaleza en toda su extensión.

Haacke centrará su trabajo en la denuncia de los mecanismos mediante los cuales el capital empresarial potenciaba y potencia su imagen de marca patrocinando o financiando exposiciones o eventos artísticos, incluso de contenidos vanguardístico-experimentales o crítico-subversivos. Haacke decidió por ello asimilar su obra a la crítica del contexto institucional en que esta aparecía. En su opinión, dado que el arte contribuye a definir nuestra cosmovisión y se presenta en un determinado espacio social, el artista ha de reflexionar sobre la naturaleza de esa imagen del mundo y desvelar los intereses que promueve. Esa pulsión se disparó tras la censura de la que fue víctima en el año 1971, cuando la obra Shapolsky et al. Manhattan Real State Holdings, a Real Time Social System, as of May 1, 1971, que presentó para la exposición individual que el Guggenheim de Nueva York iba a dedicarle, fue descartada por Thomas M. Messer, por entonces director del museo, dado que la pieza denunciaba el abandono que sufrían algunos barrios neoyorquinos como Harlem a consecuencia de la especulación urbanística liderada por grandes monopolios inmobiliarios.

Sin embargo, será sobre todo en los años 80 cuando el artista incidirá en esta temática. En Der Pralinenmeister, de 1981, ponía al descubierto las condiciones domésticas y laborales de los obreros de la fábrica de chocolate Monheim, propiedad del coleccionista de arte Peter Ludwig. Ludwig 
trataba de rentabilizar sus donaciones entrometiéndose en las políticas culturales de los museos públicos. Haacke presentó una instalación en la que desvelaba tales injerencias en imágenes donde aparecían los logos de la empresa chocolatera. En uno de los dípticos se aludía al aislamiento social de las mujeres trabajadoras de la fábrica, que según un informe de Caritas vivían recluidas en ghettos y en condiciones sociales pésimas, hasta el punto de que algunas de ellas, ante la imposibilidad de dejar a su hijos en guarderías o centros caritativos, se veían abocadas a entregarlos en adopción. La empresa, lejos de atender las peticiones de sus trabajadores y diversos agentes sociales, respondió señalando que Monheim era «una fábrica de chocolate y no un jardín de infancia» ${ }^{40}$.

MetroMobiltan, de 1985, es una de las obras de esa época en las que el artista denunció los vínculos entre capital y poder opresor en un caso que centrará su atención durante los años 80: el apartheid sudafricano. La instalación desarrollaba algunas propuestas anteriores en las que el artista sintetizaba mediante la inclusión de antenas en un barril de petróleo la importancia de los medios de comunicación en la difusión exponencial de la publicidad comercial, en cuyas campañas las empresas gastan elevadas sumas de dinero. El entablamento que recortaba la parte superior de la instalación desvelaba la relación directa entre la presencia pública del mundo empresarial y la posibilidad de esponsorizar distintos «programas, exhibiciones especiales y servicios». Por su parte, las bandas azules laterales incluían extractos de la respuesta que la empresa dio en 1981 a las demandas de diversos colectivos que clamaban por el cese de la colaboración de la entidad con la policía y el ejército del apart-

\footnotetext{
${ }^{40}$ Véase W. GRASSKAMP, M. NESBIT y J. BIRD, Hans Haacke, Londres, 2004, p. 63.
}

heid, a los que suministraba el $20 \%$ de sus necesidades energéticas. Una protesta que, posteriormente, se trasladaría al ámbito universitario estadounidense y al propio Congreso de aquel país, que sancionó a la empresa por estas actividades. Por si fuera poco, Mobil había financiado numerosas muestras del Metropolitan Museum como parte de una estrategia en la que la promoción del arte se justificaba «por el bien de los negocios», según advertía un anuncio aparecido en el New York Times el 10 de octubre de $1985^{41}$.

Estas obras de Haacke suelen ser recogidas bajo el título de «crítica institucional». El problema que se atisba en las mismas procede del hecho de que, en la medida en que sus estrategias no sepan renovarse, son fácilmente asimilables por la institución, de modo que corren el peligro de convertirse en mera «crítica de salón». Un punto que resulta tanto más acuciante si consideramos la desarticulación de los movimientos sociales que acompañaron al surgimiento del arte crítico, a los que este no hacía sino dar voz en el seno de las instituciones dominantes ${ }^{42}$.

Para concluir este artículo, abordaré brevemente a modo de epílogo los intentos de generar «simulacros críticos» que artistas como Cindy Sherman o Richard Prince llevaron a cabo a finales de los 70 y principios de los 80. Ambos creadores centraron su trabajo en la reflexión en torno a la constitución de los roles genéricos en el régimen escopofílico de la modernidad. Efectivamente, el privilegio que la tradición artística occidental ha concedido al ojo como el

\footnotetext{
${ }^{41}$ Véase Ibid., p. 13.

${ }^{42}$ Las contradicciones del arte crítico han sido lúcidamente señaladas por J. RANCIÈRE en artículos como «Estética y política: las paradojas del arte político», Las imágenes del arte, todavía, Cuenca, 2007, pp. 25-44 y libros como Sobre políticas estéticas, Barcelona, 2005.
} 
más excelso de los sentidos no puede desvincularse de un modelo de representación corporal que privilegia la frontalidad, demandada, según apuntó John Berger, por «el espectador-propietario que mira» la $\mathrm{obra}^{43}$. Este mismo autor subrayaba la difusión creciente de tal modelo fenomenológico a través de los medios de difusión masiva actuales, entre los que cuenta a la publicidad, la prensa y la televisión.

Como respuesta a la simplificación de la sexualidad y el cuerpo en el universo publicitario, el tratamiento de ambos conceptos en el arte contemporáneo sería «más amplio y diversificado» ${ }^{44}$. Más allá de ampliar el repertorio gestual y expresivo tanto del rostro en particular como del cuerpo en general, en el arte último hallamos propuestas que inciden en lo relativo a la naturaleza menstrual, escatológica o incluso abyecta del cuerpo, que constatarían frente a la eternidad epidérmica de la imagen la condición mortal del ser humano.

Desde el punto de vista estrictamente icónico, tal interés se vio acentuado cuando reivindicaciones sociales como el movimiento feminista incentivaron la creación de imágenes de la mujer alternativas a las proporcionadas por los medios de comunicación y la publicidad. En ocasiones, esa crítica aparece suscitada a partir de la recreación de los iconos mass-mediáticos en el contexto del arte, tal y como sucede en los retratos autoescenificados de Cindy Sherman. Sherman, al igual que Richard Prince, puso en liza una serie de estrategias miméticas que trataban de apropiarse de los iconos de la industria de la cultura generando simulacros a modo de injertos en una sucesión de imágenes conocidas por el gran público y que atraían por ello su atención. Se trata de una forma de apropiacionismo

\footnotetext{
${ }^{43}$ J. BERGER, Ob. Cit., p. 66.

${ }^{44}$ J. C. Perez Gauli, Ob. Cit., p. 27.
}

que pone énfasis en distanciarse de aquel que concede a los ready-mades un carácter entusiasta ante los logros de la sociedad de consumo, como sucede en el arte de Jeff Koons $^{45}$. Sherman o Prince no se apropian por ello de objetos ya fabricados, sino que intentan dislocar el sentido del imaginario instituido socialmente. Según ha destacado María del Pilar Sánchez Gómez, ambos artistas compartirían «la idea de que la creación de un nuevo simulacro es la forma más eficaz de desenmascararlo» ${ }^{46}$.

Si Sherman trabajó principalmente con la idea de mujer encarnada por las actrices del cine de serie $B^{47}$, Prince tuvo como referente principal el ámbito publicitario y el estereotipo machista del hombre americano, representado por la aventurera y audaz figura del vaquero. Trabajando a partir de imágenes que extraía directamente del espacio publicitario y que después refotografiaba, Prince perseguía desvelar «el sentido de la tradición cultural a través de la multiplicidad de signos representacionales» ${ }^{48}$. En su serie Cowboys (Lám. 12), centrada en las campaña de la marca de tabaco Marlboro, los iconos publicitarios de los que se apropiaba remitían a su vez a los estereotipos culturales creados por el western, tratando de tensionar y desactivar desde el arte ambas referencias del imaginario social. El artista recurría a una imagen extraída de la normalidad cotidiana que, desprovista de texto y de la imagen del producto al que se solía asociar, desvelaba su incon-

\footnotetext{
${ }^{45}$ Para una crítica de la denominada «escultura de bienes de consumo", véase H. FOSTER, El retorno de lo real. La vanguardia a finales de siglo, Tres Cantos, 2001, pp. $109-117$.

${ }^{46}$ Comunicación personal de la autora.

${ }^{47}$ Una recopilación íntegra de este trabajo puede consultarse en Cindy Sherman. The Complete Untitled Film Stills, Nueva York, 2003.

${ }^{48}$ Véase R. BROOKS, «A Prince of Light or Darkness?», Richard Prince, Londres, 2003, pp. 56-62.
} 
cordancia con la vida diaria del sujeto al que iba dirigido el anuncio.

Rosetta Brooks ha señalado que el contexto en que el artista creó la serie correspondía al inicio de las campañas antitabaco que contaminaban y oscurecían la imagen mítica del vaquero y la inocencia de la Arcadia romántica americana, por lo que las fotografías de Prince entablaban su dialéctica con un imaginario que comenzaba a ser desacreditado ${ }^{49}$. En todo caso, ello no invalida la principal crítica que han sufrido estas obras, derivada del hecho de que al constituirse como simulacros, tienden a consolidar el imaginario que pretendían combatir, definiéndose por su diferencia adicional.

${ }^{49}$ Ibid., pp. 56-62. 


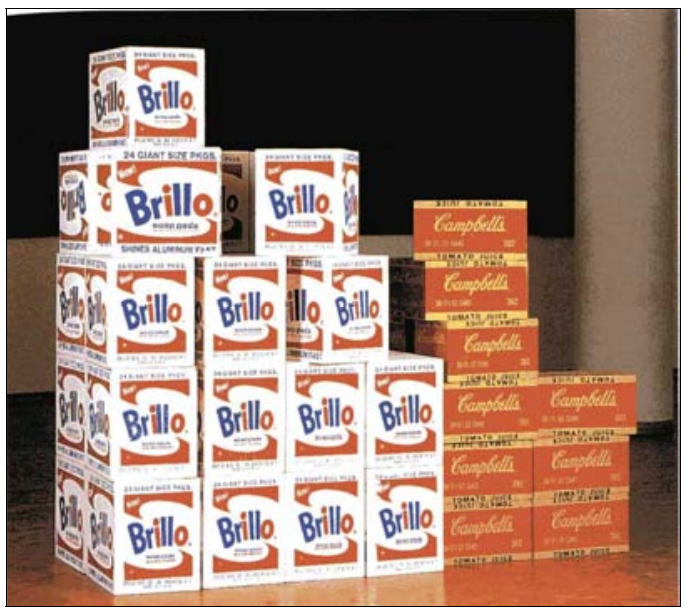

- Lám. 1. Andy Warhol, Brillo Boxes (Soap Pads) and Campbell's Boxes (Tomato Juice), 1964, Museum Ludwig, Colonia.

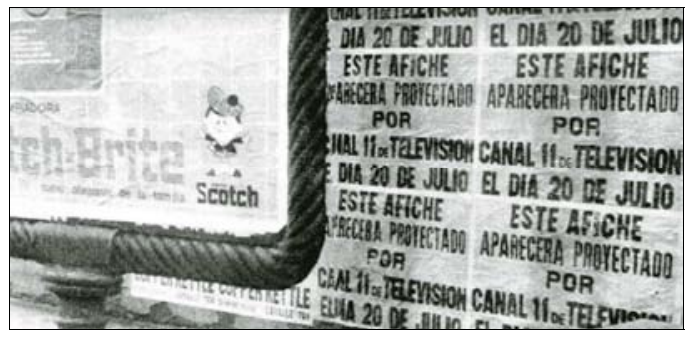

- Lám. 3. Óscar Masotta, El mensaje fantasma, 1966 (fotografía de Rubén Santantonín).

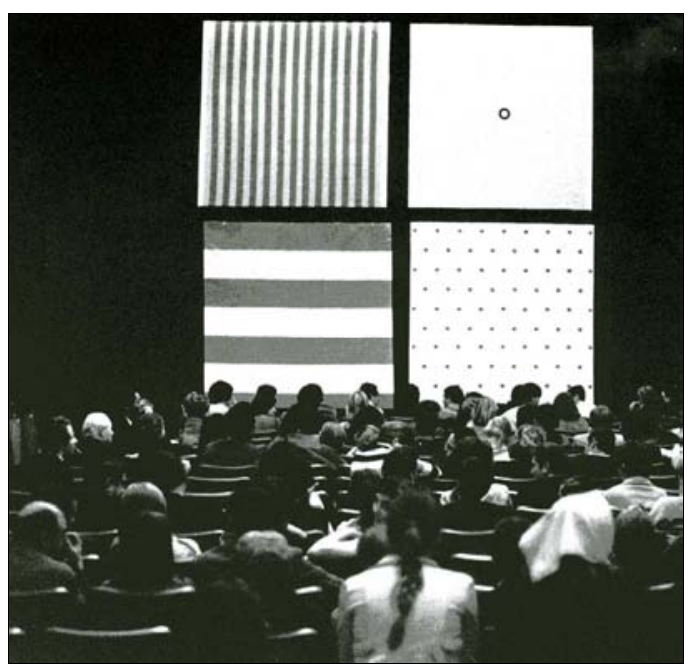

- Lám. 5. Daniel Buren, Olivier Mosset, Michel Parmentier, Niele Toroni, manifestación en el Musée des Arts Décoratifs, París, junio de 1967 (fotografía de Daniel Buren).

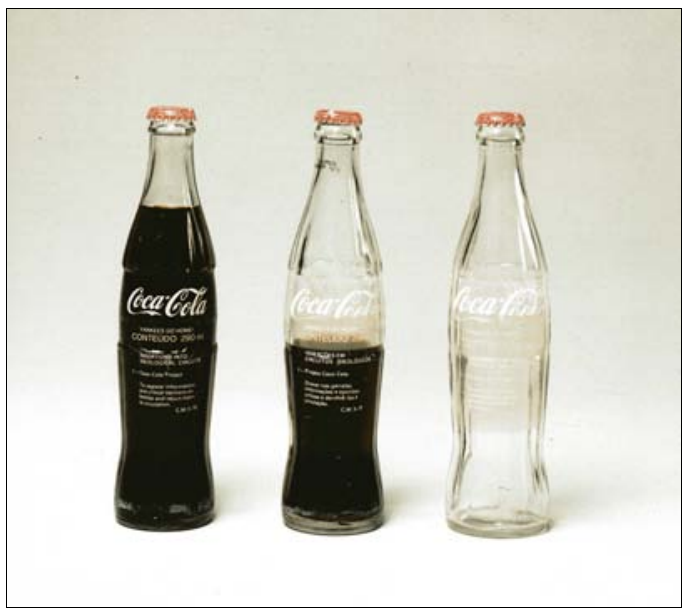

- Lám. 2. Cildo Meireles, Inserções em circuitos ideologicos, Projeto Coca-Cola, 1970, Collection New Museum of Contemporary Art, Nueva York.

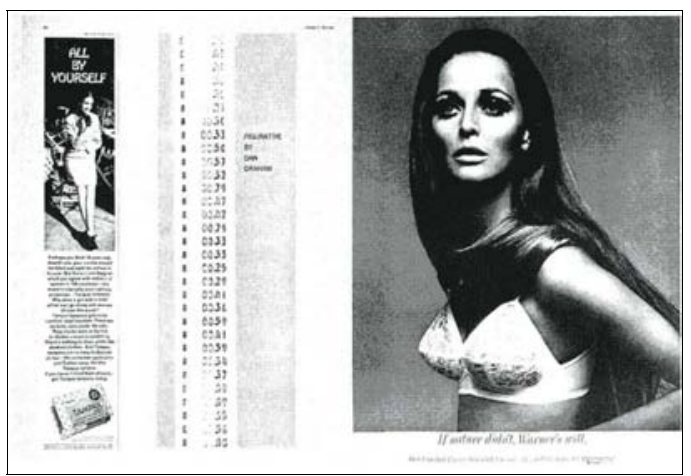

- Lám. 4. Dan Graham, Sin título (Figurative), en Harper's Bazaar, marzo de 1968, Mariam Goodman Gallery, Nueva York.

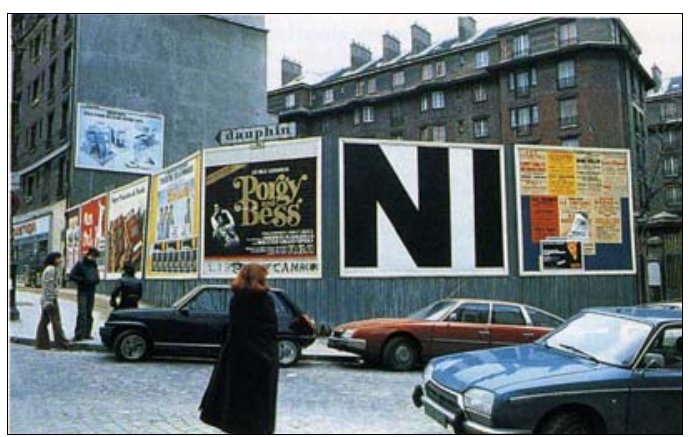

- Lám. 6. Tania Mouraud, City Performance no. 1 (Paris), 1978 (fotografía de Tania Mouraud). 


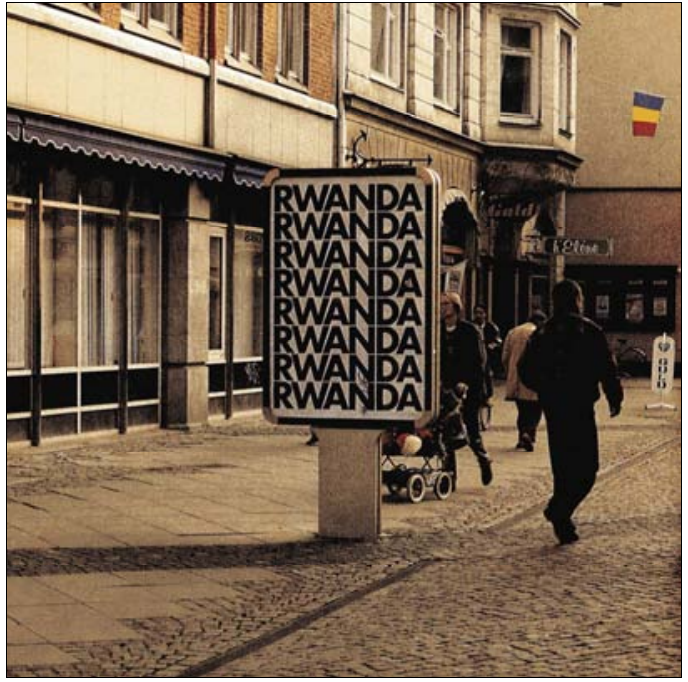

- Lám. 7. Alfredo Jaar, Rwanda, Rwanda, 1994, Thor Thordeman (Malmö) / Galerie Lelong (Nueva York).

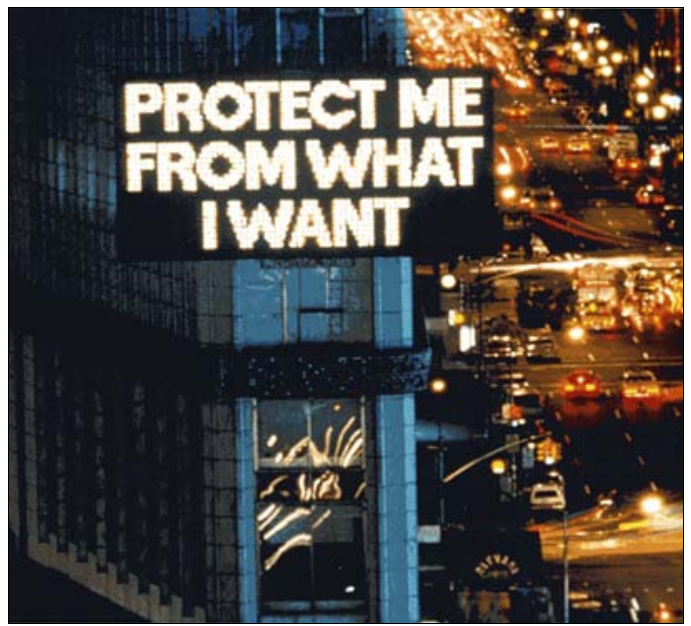

- Lám. 9. Jenny Holzer, Survival, 1985-86 (fotografía de John Marchael).

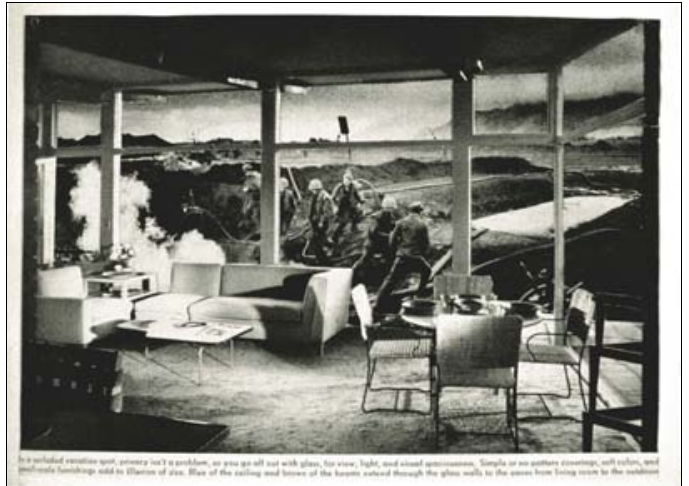

- Lám. 8. Martha Rosler, Vocation Getaway (versión periódico) Bringing the War Home: House Beautiful, 1966-1972, Martha Rosler.

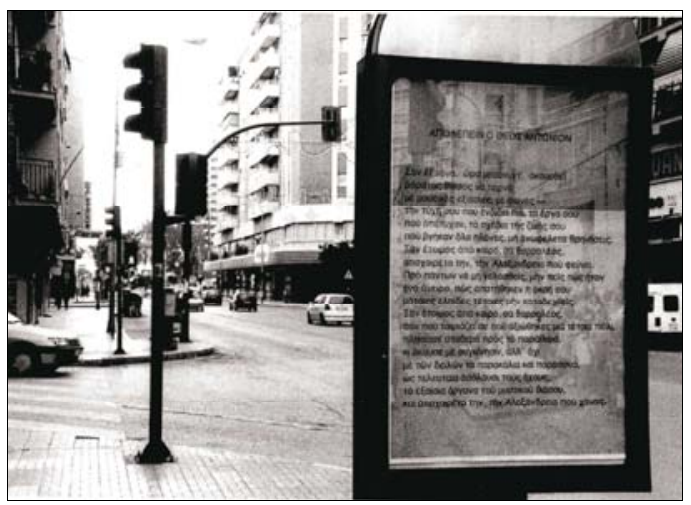

- Lám. 10. Rogelio López Cuenca, Calle Cavafis, 1998, Rogelio López Cuenca. 


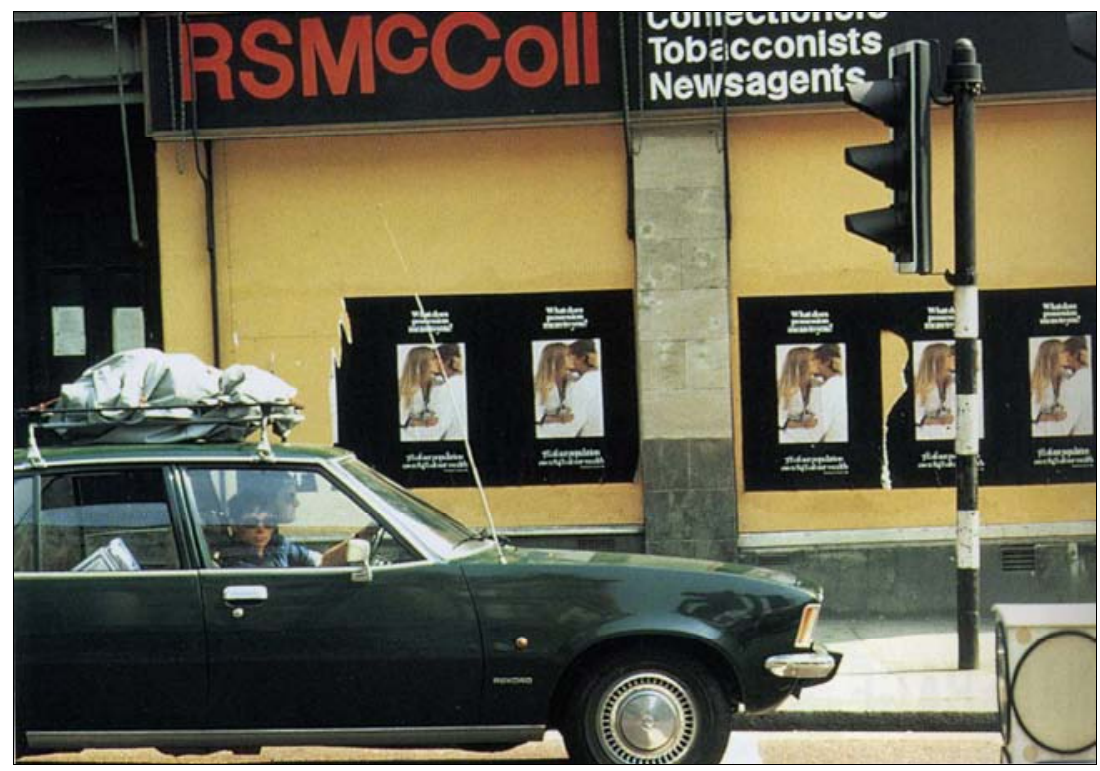

- Lám. 11. Victor Burgin, Possession, 1976 (fotografía de Sean Hudson).

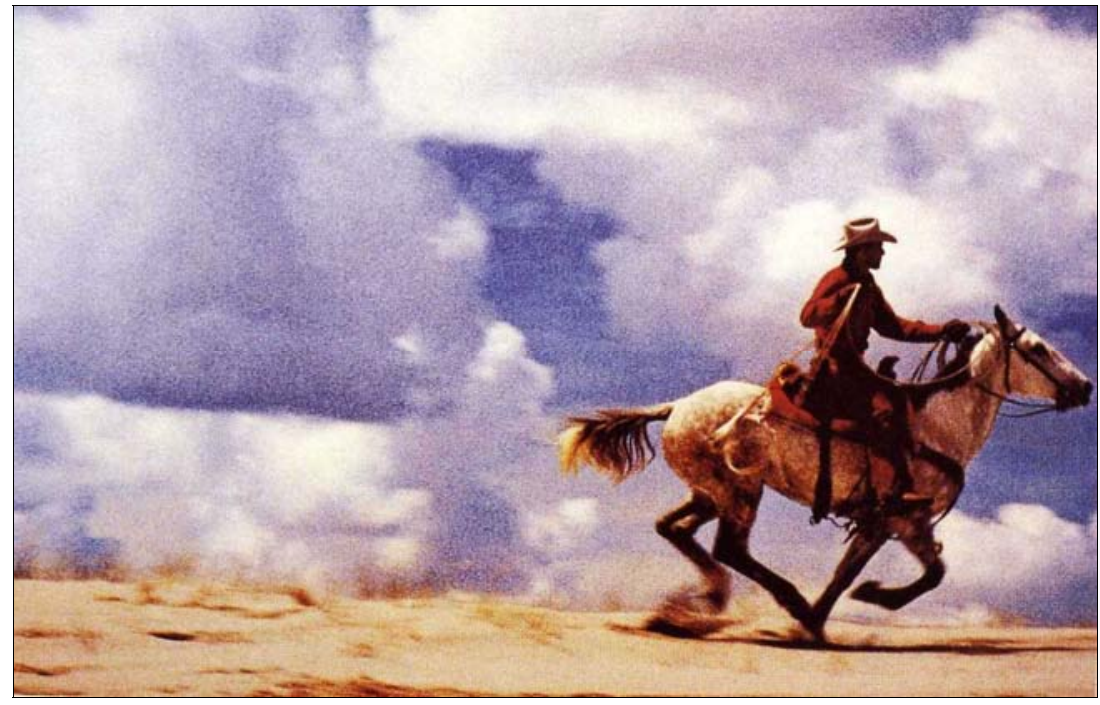

- Lám. 12. Richard Prince, Sin título (cowboy), 1989, Richard Prince. 